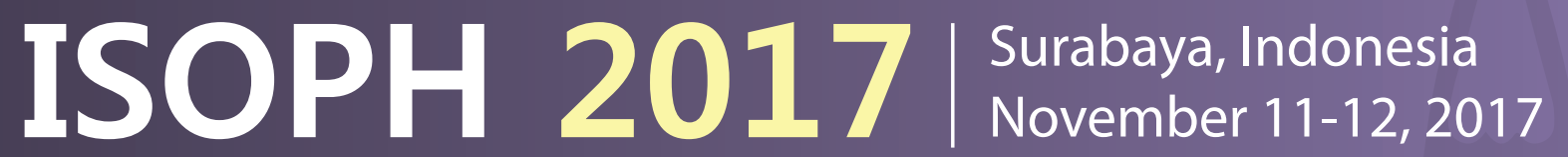 PROCEEDINGS OF THE 2ND INTERNATIONAL SYMPOSIUM OF PUBLIC HEALTH
}

\section{Achieving SDGs in South East Asia: Challenging and Tackling of Tropical Health Problems}

Editors:

I Wayan Gede Artawan Eka Putra

Agung Dwi Laksono

Yulis Setiya Dewi

Nikmatur Rohmah and

Darrimiya Hidayati

Editor on Board: Febi Dwirahmadi

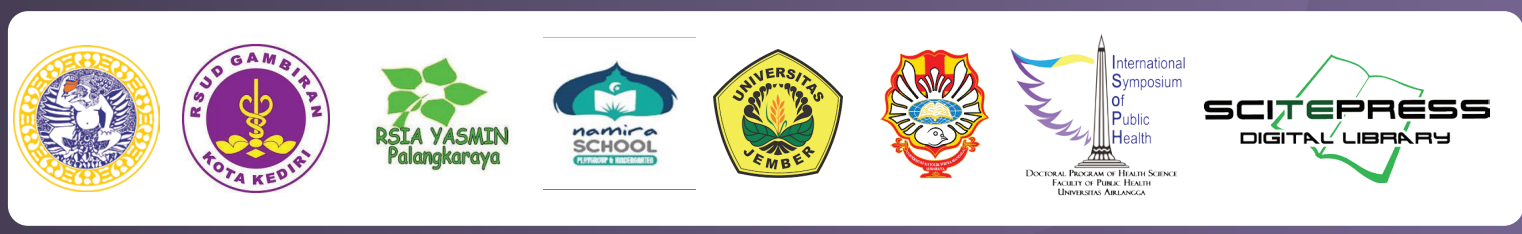


Health Problem Analysis of HIV/AIDS in the Health Office of Pasuruan District

Wardiansyah Naim, Chatarina Umbul Wahjuni and Supaat Setia Hadi

The Quality System of Early Warning, Alert, and Response System (EWARS) in The South Kalimantan Province, Indonesia

Dian Muspitaloka Hikmayati and Atik Choirul Hidajah

The Safe Duration of Benzene Exposure in the Motor Workshop Area

Erick Caravan K. Betekeneng, Abdul Rohim Tualeka, Mahmud Aditya Rifqi and Nurhayati Saridewi

Measuring The Quality of Renal Care Using Information System Design: An Early Warning System to Improve Health Care Quality

Umi Khoirun Nisak, Aditiawardana, Arief Wibowo and Hari Basuki Notobroto

Evaluation of Dengue Hemorrhagic Fever Surveillance System

Kusuma Cutwardani, Atik Choirul Hidajah and Sigunawan

Community Resilience as a Recovery Method for Psychiatric Patients: A Meta-Study

Retno Lestari and Ah Yusuf

Evaluation of an Epidemiologic Investigation and Risk Factors Study of Leptospirosis Disease

Sholikah, Atik Choirul Hidajah and Bambang Wuryono Kartika

Obstacles and Solutions for Tuberculosis Screening Among People With Diabetes Mellitus in Denpasar, Bali, Indonesia - A Need Assessment

IWG Artawan Eka Putra, PAS Astuti, IMK Duana, IK Suarjana, KH Mulyawan, NMD Kurniasari,

IBG Ekaputra, A Probandari and CU Wahjuni

Nutritional Status, Body Fat Percentage, Hemoglobin Level and Physical Fitness in A Football Athlete Ratna Candra Dewi, Nanda Rimawati and Lutfhi Abdil Khuddus

Compassion in Interprofessional Health Education is a Lagged Trigger to Quality Health and Well-being

Simon Martin Manyanza Nzilibili and Qurnia Andayani

Exploring the Role of NGOs' Health Programs in Promoting Sustainable Development in Pakistan Septi Ariadi, Muhammad Saud and Asia Ashfaq

Correlation Knowledge, Attitude and Actions with Health Complaints from Exposure of Pesticides on Horticultural Farmers

Andree Aulia Rahmat, Eska Distia Permatasari and Retno Adriyani

Description of Anthrax Outbreak Investigation in Pacitan District in 2017

Veronika Ofong, Chatarina $U . W$ and Supaat

Epidemiology of Measles in the Gresik District of Eastern Java Province from 2014 to 2016

Asrul Kaimudin, Atik Choirul Hidajah and Bambang Wuryono Kartika

Analysis of Factors That Affect Family Centered Empowerment while Caring for Children with Leukemia

Yuni Sufyanti Arief, Nursalam, IDG Ugrasena and Shrimarti R. Devi

Zinc Status and Cadmium Exposure in Stunted Children Aged from 24 to 59 Months: A Cross Sectional Study

Sulistiyani, Leersia Yusi R., Ninna Rohmawati, Ruli Bahyu Antika, Bambang Wirjatmadi and

Merryana Adriani 


\title{
Community Resilience as a Recovery Method for Psychiatric Patients: A Meta-Study
}

\author{
Retno Lestari ${ }^{1}$ and Ah Yusuf ${ }^{2}$ \\ ${ }^{1}$ Student of Doctoral Program of Health Science, Faculty of Public Health, Universitas Airlangga, Mulyorejo, Surabaya, \\ Indonesia \\ ${ }^{2}$ Faculty of Nursing, Universitas Airlangga, Mulyorejo, Surabaya, Indonesia \\ retno.lestari98@gmail.com,ah-yusuf@fkp.unair.ac.id
}

Keywords: Community resilience, mental health, recovery, psychiatric patients, meta-study.

\begin{abstract}
Community resilience is the adaptive capacity of a community to respond to and recover from adversities. Through communities, psychiatric patients can recover and improve their emotional, social and thinking skills needed in everyday life. The purpose of this study is to describe the results of a meta-study of community resilience as a method for recovery process in psychiatric patients. The method in this study used several approaches of meta-study and was guided by Thorne (2006). Meta-analysis was used to compare the studies, based on 125 data sources: Science Direct, Google Scholar, Proquest Health and Medical Complete, Proquest Nursing and Allied Health Source, Proquest Psychology Journals and Proquest Science Journals from 2007 to 2017. Subsequently three common themes emerged: 'vulnerability in the community', 'protecting each other' and 'high spirituality within community'. The first of these comprised several subthemes including feeling sad, isolated and going through hardship in life. The second theme included social resilience, economic reliance and resilience of all dimensions. The latter theme included self-protection, self-reliance and spirituality growth. Resilient communities could support a recovery process among psychiatric patients. It is recommended that health professionals in a community could promote the development of community resilience to increase wellbeing.
\end{abstract}

\section{INTRODUCTION}

Studies about the recovery process of psychiatric patients in a community have been well researched. However, there is a lack of research explained about the recovery experiences in a community. Building community resilience is as important as investigating individual resilience because it also builds connections with each other. Resilience is not just about individual abilities, but also the systems surrounding which are affected (Sumskis et al., 2016).

A recovery-oriented approach for patients is needed in the community. Routine activities are engaging in social relationships and could promote a recovery process for the patients. However, this routine could not be implemented if the communities could not provide a resilient model for the individual (Drake and Whitley, 2014).

Every individual has problems, challenges and difficulties, and therefore everyone needs to be resilient to face these challenges. Untreated chronic stress could influence health conditions (Sumskis et al., 2016). Chan (2017) recommended evidencebased practice in treating psychiatric patients. Social and occupational recovery is needed to improve daily routines among patients which included family therapy, resilience therapy and engaging in social activities in a community.

Community resilience is the adaptive capacity of a community to respond to and recover from adversities. Through communities, psychiatric patients can recover and improve their emotional, social and thinking skills needed in everyday life. Psychosocial stressors need to be adapted with support from family and communities (Somasundaram and Sivayokan, 2013).

Community resilience is neighborhood resilience; it provides social support and promotes a resilient model for individuals. However, previous studies could not explain the theory regarding how to be resilient communities in detail. Community resilience is more than about developing communities with regard to providing support for 
communities; it is a capability approach to achieve wellbeing and resilience (Allmark et al., 2014).

Sayers et al. (2017) stated that service and infrastructure are two vital aspects that have to be considered in supporting a recovery process for patients in the community. Health care professionals should improve their knowledge about how to build relationships with patients and provide therapies. In addition, policies and equity programmes should improve the recovery goals for patients. Therefore, the purpose of this study is to describe results of a meta-study of community resilience as a method for the recovery process in psychiatric patients.

\section{METHODS}

The method in this study used several approaches of meta-study and was guided by Thorne (2006). Metaanalysis was used to compare the studies, based on 125 data sources: Science Direct, Google Scholar, Proquest Health and Medical Complete, Proquest Nursing and Allied Health Source, Proquest Psychology Journals and Proquest Science Journals from 2007 to 2017 . The following inclusion criteria were used:

- Research published in a referred publication in nursing and health care, from 2007 to 2017. The sample consisted of 10 articles.

- A qualitative study in which the subjective experiences of psychiatric patients' recoveries in a community from their own perspectives were investigated.

- Studies provided sufficient data about psychiatric patients' recoveries in a community and being resilient in the community.

According to Thorne (2017), qualitative metasynthesis aims to reveal a new knowledge by broadening the conceptual theories, methodologies and interpreting the main findings, instead of conducting a conventional literature review. Qualitative metasynthesis is a research method which produces a more comprehensive, systematic and well-established outcome (Thorne, 2015). Studying human experiences is challenging and they are difficult to generalize into a singular meaning. In addition, studying qualitative metasynthesis could develop the value of qualitative health studies into more evidence-based practice (Thorne, 2006; Thorne, 2013).

A meta-study has been used extensively in health care to form a new interpretation (Ring et al., 2011), and it brought a connection among meta-themes. There are three analytical phases included in metastudy (Thorne, 2006):

- Meta-theory: revealing the bases of theories as the frameworks which are grounded in the study results;

- Meta-method: reviewing the rigor, epistemological rationale for the study methods used;

- Meta-data analysis: analyzing the data in previous qualitative studies.

We identified 125 articles from the literature searches to be screened for the study. 110 articles were excluded based on the inclusion criteria. The abstracts of 35 articles were investigated to determine if the study explained about recovery in a community which was needed to treat psychiatric patients. 25 articles that did not meet the criteria for qualitative research of methodological rigor were rejected. 10 qualitative articles were selected as the most applicable qualitative research on recovery for psychiatric patients in community.

\section{RESULTS}

Ten qualitative studies were included. Some of the insights were obtained from 10 extensive qualitative studies of community resilience. Subsequently, three common themes emerged: "vulnerability in the community', 'protecting each other' and 'high spirituality within the community'. The former of these comprised several subthemes including feeling sad, isolated and going through hardship in life. The second theme included social resilience, economic reliance and resilience of all dimensions. The latter theme included self-protection, self-reliance and spirituality growth. Metasynthesis studies, which can be seen in Table 1, explained the needs for community resilience as a recovery method for psychiatric patients, 2007 to November 2017.

Table 1: Metasynthesis studies from 2007 to November 2017.

\begin{tabular}{|c|c|c|}
\hline $\begin{array}{c}\text { Researcher(s), } \\
\text { year, country } \\
\text { and } \\
\text { background }\end{array}$ & $\begin{array}{c}\text { Research } \\
\text { focus }\end{array}$ & $\begin{array}{c}\text { Method(s) and } \\
\text { findings }\end{array}$ \\
\hline $\begin{array}{c}\text { Mazor \& } \\
\text { Doron, 2011, } \\
\text { Israel, School } \\
\text { of Social Work }\end{array}$ & $\begin{array}{c}\text { Community } \\
\text { rehabilitation } \\
\text { for } \\
\text { schizophreni } \\
\text { a patients }\end{array}$ & $\begin{array}{c}\text { Phenomenology, 15 } \\
\text { participants. } \\
\text { Analysis to } \\
\text { categories-themes. } \\
\text { Recovery from }\end{array}$ \\
\hline
\end{tabular}




\begin{tabular}{|c|c|c|}
\hline & & $\begin{array}{l}\text { mental illness } \\
\text { means as full } \\
\text { recovery, social } \\
\text { recovery }\end{array}$ \\
\hline $\begin{array}{c}\text { Peterson } \text { et al., } \\
2015, \\
\text { Denmark, } \\
\text { Public Health }\end{array}$ & $\begin{array}{c}\text { Recovery } \\
\text { from mental } \\
\text { illness }\end{array}$ & $\begin{array}{c}\text { Phenomenology, } 12 \\
\text { participants, } \\
\text { Giorgi's analysis. } \\
\text { The recovery } \\
\text { process is affected } \\
\text { by learning, social } \\
\text { relations and } \\
\text { willpower. }\end{array}$ \\
\hline $\begin{array}{c}\text { Shepherd } \text { et al., } \\
\text { 2017, UK, } \\
\text { Psychiatrist }\end{array}$ & $\begin{array}{l}\text { Recovery in } \\
\text { personality } \\
\text { disorder in } \\
\text { the } \\
\text { community }\end{array}$ & $\begin{array}{l}\text { Qualitative, } 41 \\
\text { participants, } \\
\text { thematic analysis. } \\
\text { Recovery means as } \\
\text { developing a sense } \\
\text { of self, feeling } \\
\text { connected and } \\
\text { identity, needs a } \\
\text { social space to } \\
\text { develop in the } \\
\text { community. }\end{array}$ \\
\hline $\begin{array}{l}\text { Nourianet al., } \\
\text { 2016, Iran, Phd } \\
\text { Candidate }\end{array}$ & $\begin{array}{l}\text { Resilience in } \\
\text { adolescents }\end{array}$ & $\begin{array}{l}\text { Phenomenology, } 8 \\
\text { adolescents, Van } \\
\text { Manen analysis. } \\
\text { Going through } \\
\text { hardship in life, } \\
\text { feeling upset. } \\
\text { Governmental } \\
\text { communities } \\
\text { develop their } \\
\text { resilience, and } \\
\text { spirituality growth. }\end{array}$ \\
\hline $\begin{array}{l}\text { Pressley and } \\
\text { Smith, 2017, } \\
\text { USA, Trauma } \\
\text { Center }\end{array}$ & $\begin{array}{l}\text { Resilience in } \\
\text { under- } \\
\text { resourced } \\
\text { communities }\end{array}$ & $\begin{array}{l}\text { Grounded theory, } \\
20 \text { participants, } \\
\text { Interpretive } \\
\text { analysis. } \\
\text { Community } \\
\text { supports for } \\
\text { participants to } \\
\text { continue the life. }\end{array}$ \\
\hline $\begin{array}{c}\text { Gillard et al., } \\
\text { 2015, UK, } \\
\text { Population } \\
\text { Health } \\
\text { Research } \\
\text { Institute }\end{array}$ & $\begin{array}{l}\text { Recovery in } \\
\text { personality } \\
\text { disorders }\end{array}$ & $\begin{array}{c}\text { Qualitative, } \\
6 \text { participants. } \\
\text { Complementary } \\
\text { thematic and } \\
\text { framework analysis. } \\
\text { Feeling isolated, } \\
\text { Key concepts of } \\
\text { recovery included in } \\
\text { social relationships } \\
\text { and broader } \\
\text { interaction with } \\
\text { others in } \\
\text { community. }\end{array}$ \\
\hline Bredskiet al., & What in- & A cross sectional \\
\hline
\end{tabular}

\begin{tabular}{|c|c|c|}
\hline $\begin{array}{l}\text { 2015, UK, } \\
\text { Psychiatrist }\end{array}$ & $\begin{array}{l}\text { patients want } \\
\text { in their } \\
\text { recovery }\end{array}$ & $\begin{array}{l}\text { study, } 31 \text { patients, } \\
\text { thematic analysis. } \\
\text { Recovery process } \\
\text { needs hope, good } \\
\text { social relations with } \\
\text { friends, families and } \\
\text { good environments } \\
\text { in the community. }\end{array}$ \\
\hline $\begin{array}{l}\text { Bromley et al., } \\
\text { 2013, CA, PhD }\end{array}$ & $\begin{array}{c}\text { Experiencing } \\
\text { Community: } \\
\text { serious } \\
\text { mental } \\
\text { illness }\end{array}$ & $\begin{array}{l}\text { Grounded theory, } \\
30 \text { participants. } \\
\text { Thematic data } \\
\text { analysis was used. } \\
\text { Living in } \\
\text { community means } \\
\text { having meaningful } \\
\text { help, reducing } \\
\text { stigma, and offering } \\
\text { help to others. }\end{array}$ \\
\hline $\begin{array}{c}\text { Moxham et al., } \\
\text { 2017, } \\
\text { Australia, } \mathrm{PhD}\end{array}$ & $\begin{array}{l}\text { Living in } \\
\text { recovery } \\
\text { camp }\end{array}$ & $\begin{array}{c}\text { Qualitative, } 27 \\
\text { participants. } \\
\text { Content analysis } \\
\text { was used. } \\
\text { Participants felt a } \\
\text { connection with } \\
\text { each other, improve } \\
\text { positive habits, } \\
\text { accept challenge } \\
\text { and recover in the } \\
\text { community. }\end{array}$ \\
\hline $\begin{array}{l}\text { Soygur et al., } \\
\text { 2017, Turkey, } \\
\text { Assoc. Prof. }\end{array}$ & $\begin{array}{l}\text { Qualitative } \\
\text { analysis of } \\
\text { factors } \\
\text { contributing } \\
\text { to recovery } \\
\text { from the } \\
\text { perspective } \\
\text { of } \\
\text { schizophreni } \\
\text { a patients }\end{array}$ & $\begin{array}{c}\text { Phenomenology, } 24 \\
\text { participants, NVivo } \\
\text { analysis. Recovery } \\
\text { process needs a } \\
\text { warm environment } \\
\text { which gives hope, } \\
\text { encouragement, } \\
\text { ability to support } \\
\text { and purposeful life. } \\
\text { Recovery-oriented } \\
\text { approach requires a } \\
\text { genuine and } \\
\text { informal } \\
\text { environment. }\end{array}$ \\
\hline
\end{tabular}

Meta-data analysis was applied to review the themes which emerged in previous studies as seen in Table 2. The research findings reveal the complexities of the phenomenon and the characteristics of community resilience. The three common themes which emerged were as follows: 
Table 2: Codes, categories and themes.

\begin{tabular}{|c|c|c|}
\hline Codes & Categories & Themes \\
\hline $\begin{array}{l}\text { Avoiding } \\
\text { problems }\end{array}$ & Feeling hard & \multirow{3}{*}{$\begin{array}{l}\text { Vulnerability in the } \\
\text { community } \\
\text { (Nourian } \text { et al., } \\
2016 ; \\
\text { Pressley and Smith, } \\
2017 ; \\
\text { Gillard } \text { et al., 2015) }\end{array}$} \\
\hline $\begin{array}{c}\text { Isolate their } \\
\text { self }\end{array}$ & $\begin{array}{l}\text { Feeling } \\
\text { isolated }\end{array}$ & \\
\hline $\begin{array}{l}\text { Extremely } \\
\text { difficult }\end{array}$ & $\begin{array}{c}\text { Going } \\
\text { through } \\
\text { hardship in } \\
\text { life }\end{array}$ & \\
\hline Social relations & $\begin{array}{l}\text { social } \\
\text { resilience }\end{array}$ & \multirow{3}{*}{$\begin{array}{c}\text { Protecting each } \\
\text { other } \\
\text { (Mazor and Doron, } \\
2011 ; \\
\text { Peterson } \text { et al., } \\
\text { 2015; } \\
\text { Shepherd } \text { et al., } \\
\text { 2017; } \\
\text { Bredskiet al., 2015) }\end{array}$} \\
\hline $\begin{array}{c}\text { Financial } \\
\text { independence }\end{array}$ & $\begin{array}{l}\text { economic } \\
\text { reliance }\end{array}$ & \\
\hline Full recovery & $\begin{array}{l}\text { resilience of } \\
\text { all } \\
\text { dimensions }\end{array}$ & \\
\hline $\begin{array}{l}\text { Bonding with } \\
\text { God }\end{array}$ & $\begin{array}{c}\text { self- } \\
\text { protection }\end{array}$ & \multirow{3}{*}{$\begin{array}{l}\text { High spirituality } \\
\text { within community } \\
\text { (Nourian } \text { et al., } \\
2016 ; \\
\text { Pressley and Smith, } \\
\text { 2017; } \\
\text { Gillard } \text { et al., 2015; } \\
\text { Bromley et al., } \\
\text { 2013; } \\
\text { Moxham } \text { et al., } \\
\text { 2017; } \\
\text { Soyguret al., 2017) }\end{array}$} \\
\hline Being resilient & self-reliance & \\
\hline $\begin{array}{c}\text { Having } \\
\text { positive goals }\end{array}$ & $\begin{array}{l}\text { spirituality } \\
\text { growth }\end{array}$ & \\
\hline
\end{tabular}

\section{DISCUSSION}

The meta-method and the meta-theory reflected the theoretical underpinnings of this research. Three common themes emerged: "vulnerability in the community', 'protecting each other' and 'high spirituality within the community'.

Vulnerability is not about individuals' failures, but it happens as the system could not understand the exact problems surrounding the patients (Sumskis et al., 2016). Iacoviello and Charney (2014) explained that psychosocial factors could also affect the range of individual resilience. Traumatic experiences could prevent psychiatric patients from becoming resilient. Resilience means facing challenges and dealing with difficult situations. Therefore, it is health care where professionals should provide support for patients to develop adaptive coping strategies.

Protecting each other means having a continuous social support from families and communities.
Social resilience, economic resilience and overall resilience are three component factors needed in recovery. Steiner and Markantoni (2014) investigated that social resilience had a better score compared to economic resilience. This means that social resilience could affect all dimensions of resilience. A lower score for economic resilience means that there were difficulties in finding employment.

Chung et al. (2014) stated that almost half of the participants believe in God as the source for resilience. Participants felt that they could seek help from God to reduce their stress. It was found that most respondents became resilient through enhancing spiritual activities and cultivating relationships with close relatives.

According to Iacoviello and Charney (2014), there are several psychotherapy techniques that can be used to be a resilient person which included being optimistic, having active coping skills, building social networks and engaging in routine activities.

Iacoviello and Charney (2014) stated that there are five psychosocial factors which relate to individual resiliency:

- observing a good resilient role model;

- building support through social networks;

- having an adequate coping strategy;

- doing physical exercise;

- providing self-actualization.

Fostering individual resilience could stimulate the development of community resilience. In addition, resilient communities could support mental health among individuals.

\section{CONCLUSIONS}

The review concludes that resilient communities could support a recovery process among psychiatric patients. It is recommended that health professionals in a community could promote the development of the community's resilience to increase wellbeing.

\section{ACKNOWLEDGEMENTS}

We would like to express our special thanks to the Head of the Doctoral Program of Health Science and the Dean of Faculty of Public Health, University of Airlangga.We also received support from the University of Brawijaya to conduct this study. 


\section{REFERENCES}

Allmark, P., Bhanbhro. S., Chrisp, T., 2014. An Argument Against The Focus on Community Resilience in Public Health. BMC Public Health, Vo.14, No.62, [Accessed 29 November 2017], Available from: URL: http://www.biomedcentral.com/1471-2458/14/62.

Bredski, J., Forsyth, K., Mountain, D., Harrison, M., Irvine, L., Maciver, D., 2015. What In-patients Want: A Qualitative Study of What's Important to Mental Health Service Users in Their Recovery (Wayfinder Partnership).Mental Health Review Journal, Vol.20, No.1, pp.1-12.

Bromley, E., Gabrielian, S., Brekke, B., Pahwa, R., Daly, K.A., Brekke, J.S., Braslow, J.T., 2013. Experiencing Community: Perspectives of Individuals Diagnosed as Having Serious Mental Illness. Psychiatric Services, Vol.64, No.7, 672-679.

Chan, S., 2017. Schizophrenia and Psychosis: Diagnosis, Current Research Trends, and Model Treatment Approaches with Implications for Transitional Age Youth. Child AdolescPsychiatric Clin N Am, 26, 341366.

Chung, B., Meldrum, M., Jones, F., Brown, A., Jones, L., 2014. Perceived Sources of Stress and Resilience in Men in an African American Community. Progress in Community Health Partnerships: Research, Education, and Action, Vol. 8, No. 4, 441-451.

Davidson, L., Shaw, J., Welborn, S., Mahon, B., Sirota, M., Gilbo, P., McDermid, M., Fazio, J., Gilbert, C., Breetz, S., Pelletier, J.F., 2010. "I don't know how to find my way in the world": Contributions of User-Led Research to Transforming Mental Health Practice. Psychiatry, Vol. 73, No. 2, pp. 101-11.

Drake, R.E., Whitley, R., 2014. Recovery and Severe Mental Illness: Description and Analysis. CanJPsychiatry, 59(5), 236-242.

Gillard, S., Turner, K., Neffgen, M., 2015. Understanding Recovery in The Context of Lived Experience Personality Disorders: A Collaborative, Qualitative Research Study, BMC Psychiatry, 15, 183, [Accessed 29 November 2017], Available from: URL: http://10.1186/s12888-015-0572-0.

Iacoviello, B.M., Charney, D.S., 2014. Psychosocial Facets of Resilience: Implications for Preventing Posttrauma Psychopathology, Treating Trauma Survivors, and Enhancing Community Resilience, European Journal of Psychotraumatology, 5, 23970, [Accessed 29 November 2017], Available from: URL: http://dx.doi.org/10.3402/ejpt.v5.23970.

Mazor, U., Doron, I., 2011. The Meaning of Community Rehabilitation for Schizophrenia Patients in Israel. Community Ment Health J, 47, 351-360.

Moxham, L., Taylor, E.K., Perlman, D., 2017. Goal Setting among People Living with Mental Illness: A Qualitative Analysis of Recovery Camp,Issues in Mental Health Nursing, [Accessed 29 November 2017], Available from: URL: http://DOI: 10.1080/01612840.2016.1271067
Nourian, M., Shahbolaghi, F.M., Tabrizi, K.N., Rassouli, M., Biglarrian, A., 2016. The lived experiences of resilience in Iranian adolescents living in residential care facilities: A hermeneutic phenomenological study. Int J Qualitative Stud Health Well-being Vol. 11, No. 30485, pp. 1-11.

Petersen, K.S., Friis, V.S., Haxholm. B.L., Nilesen, C.V., Wind, G., 2015. Recovery from Mental Illness: A Service User Perspective on Facilitators and Barriers. Community Ment Health J, 51, 1-13.

Pressley, J., Smith, R., 2017. No Ordinary Life: Complex Narratives of Trauma and Resilience in UnderResourced Communities. Journal of Aggression, Maltreatment and Trauma, Vol.26, No.2, 137-154, [Accessed 29 November 2017], Available from: URL: http://dx.doi.org/10.1080/10926771.2016.1246500.

Reddy, S.K., Thirtalli, J., Channaveerachari, N.K., Reddy, K.N., Ramareddy, R.N., Rawat, V.S., Narayana, M., Ramkhrisna, J., Gangadhar, B.N., 2014. Factors influencing access to psychiatric treatment in persons with schizophrenia: A qualitative study in a rural community. J Psychiatry, Vol. 56, No. 1, pp. 54-60.

Ring, N., Ritchie K., Mandava L., Jepson R., 2011. A Guide to Synthesising Qualitative Research for Researchers Undertaking Health Technology Assessments and Systematic Reviews, NHS Quality Improvement Standard. [Accessed 29 November 2017], Available from: URL: http://www.nhshealthquality.org/nhsqis/8837.html.

Sayers, J.M., Cleary, M., Hunt, G.E., Burmeister, O.K., 2017. Service and Infrastucture Needs to Support recovery Programmes for Indigenous Community Mental Health Consumers. International Journal of Mental Health Nursing, 26, 142-150.

Shepherd, A., Sanders, C., Shaw, J., 2017. Seeking to Understand Lived Experiences of Personal recovery in Personality Disorder in Community and Forensic Settings-A Qualitative Methods Investigation. BMC Psychiatry, 17, 282.

Somasundaram, D., Sivayokan, S., 2013. Rebuilding community resilience in a post-war context: developing insight and recommendations - a qualitative study in Northern Sri Lanka. International Journal of Mental Health Systems, Vol. 7, No. 3, pp. $1-24$.

Soygur, H., Avcioglu, M.M.Y., TekinEraslan, P., AttepeOzden, S., 2017. Lessons Learned from Experiencing Mavi AT Café (Blue Horse Café) During Six Years: A Qualitative Analysis of Factors Contributing to Recovery from The Perspective of Schizophrenia Patients. Tourkish Journal of Psychiatry, [Accessed 29 November 2017], Available from: URL: http://doi: 10.5080/u18141.

Steiner, A., Markantoni, M., 2013. Unpacking Community Resilience through Capacity for Change. Community Development Journal, Vol.48, No.3, pp. 407-425, [Accessed 29 November 2017], Available from: URL: http://doi:10.1093/cdj/bst042.

Sumskis, S., Moxham, L., Caputi, P., 2016. Meaning of Resilience as Described by People with Schizophrenia. 
International Journal of Mental Health Nursing, [Accessed 29 November 2017], Available from: URL: http://doi: 10.1111/inm.12268.

Thorne, S., 2006. Can Qualitative Metasynthesis Make a Contribution to Evidence-Based Practice? Issues and Challenges in an Era of Research Integration. Panel Presentation for: Advances in Qualitative Methods. University of British Columbia.

Thorne, S., 2013. The Promise and Pragmatics of Qualitative Metasynthesis. Physical Therapy Reviews, 18(3), 217-218.

Thorne, S., 2017. Metasynthetic Madness: What Kind of Monster Have We Created? Qualitative Health Research, Vo. 27(1), 3-12.

Thorne, S., 2015. Qualitative Metasynthesis: a Technical Exercise or a Source of New Knowledge? PsychoOncology, 24, 1347-1348. 